\title{
Dynamics of the Trade Balance: An empirical investigation of Nigerian J-Curve Hypothesis
}

\author{
${ }^{1}$ Danmola, Rasaq Akonji, ${ }^{2}$ Abba Mohammed Wakili, ${ }^{3}$ OLadipo Kolapo Sakiru \\ ${ }^{I}$ Department of Economics, Lagos State University, Ojo, Lagos State, Nigeria. \\ ${ }^{2}$ Dept of Agric, Federal College of Education, Yola, Adamawa State, Nigeria. \\ ${ }^{3}$ Department of Human Resource Development, University Putra Malaysia. Malaysia
}

\begin{abstract}
The study examine the validity of J-curve Hypothesis in the Nigerian economy, the study employs Cointegration, Vector Auto regression Estimate, Granger Causality and Variance Decomposition to analyze the hypothesis. the study shows there is absence of long-run relationships among variables under consideration but the study found short run relationship between exchange rate devaluation and trade balance through Granger causality test and therefore confirming the existence of J-curve hypothesis i.e domestic currency devaluation have bi-directional effect on trade balance in the short-run but with little effect in the long-run and hence, the needs to diversified the sources of foreign exchange apart from petroleum sector, so as to benefit from the initial devaluation of the domestic currency, in term of increasing their exports earnings.
\end{abstract}

Keywords: J-curve effect, Devaluation, Vector Auto regression Estimate, Granger Causality and Variance Decomposition.

\section{Introduction}

It has been acknowledged among policy makers and international economists that reduction in the value of country's currency vis-à-vis the rest of the world normally generate some kind of positive competitive edge in international trade. In a situation when a country deliberately lower the value of its currency, this make domestic export goods cheaper relative to its trading partners resulting in an increase in quantity demanded and hence, reducing the extent of balance of payment deficit in her current account balance. Devaluation has become inevitable in view of the recurring deficit in the balance of payment and as alternative policy option available to improve balance of trade.

The J-curve hypothesis is the term to demonstrate the effect of currency devaluation on a country's balance of trade. The theoretical understanding of the hypothesis derived from the works of both Alfred Marshall and Abba Lerner and where it was stated that "if initial balance of trade is Zero, and if the supply elasticities are infinite, then the absolute values of exports and imports elasticities have to be at least large enough to add up to unity to have an exchange rate devaluation and brings about the surplus in balance of payment". [1] believed that the theory can be established at looking at the changes in elasticity overtime. He further stated that, with time, elasticities becomes bigger and passing the threshold point described by MarshallLerner, thus bringing about situation for an improvement in balance of payment. This hypothesis gathered momentum following 1973 breakdown of exchange rate control stipulated by the Bretton-Woods institutions and the establishment of a largely-flexible or market oriented pricing mechanisms for currencies.

Devaluation has been described as a policy prescription aimed at strengthen the trade balance, but the impact of devaluation normally entails time lag before showing any impact of trade balance and hence, the effect of both short and long run impacts of depreciation on trade are quite different. At theoretical level, it worsen trade balance situation initially after devaluation, but with time, it start to show positive impact until long-run equilibrium is achieved. The time path through which the trade balance follows generate a J-curve effect. The time-lag is a product of an effect of series of several lags such as production, regulation, decision and delivery [2]. With emergence of real devaluation, traders must wait to appreciate the fact that it takes time to recognize the changes in market competiveness and period lags is normally take longer period at international market than in domestic market before information is disseminated to the various stakeholders due to distance and language problems associated with the international market. Apart from this, it normally take time in even deciding on what business relationship to go into and the replacement of new orders. There are delivery lags that explain the time taken before payments are made for new order that were placed soon before the price change. Procurement of new materials may be allowed to wait pending the time when inventories of materials are used up and this is replacement lag. Lastly, the emergence of production lags and before which producers becomes sure that present market conditions will provide a profitable opportunity. 


\section{1:2 Exchange Rate Determinations In Nigeria}

The 1970s oil boom in Nigeria changed the sources of foreign exchange earning of the country from being an agrarian economy to the oil producing country. The emergency of the oil boom tremendously improve the revenue earnings from oil sector at the detriment of agricultural sector and hence, the sector was relegated to the background. This relegation of agricultural sector emerged as result of inappropriate exchange rate policy regime in place and made the price of agricultural produce unattractive to farmers in the sector. During 1970s oil boom era, Nigeria maintained a fixed exchange regime intended to promote over-valuation of the domestic currency, which in turn encouraged importation of manufactured goods on one hand, and at same time discouraged the exportation of domestic goods, which would have boosted the domestic production and increase foreign exchange earnings for the country.

With emergence of oil crisis occasioned by oil price collapsed in the international oil market, led to the introduction of structural adjustment programme in June, 1986 and this policy created a serious setback for exchange rate management in Nigeria. The essence of the policy was to deregulate the domestic economies, so as to compete with the rest of the world. The policy focused in ensuring efficiency in resource utilization; avoid wastage in economic management, removal of continued misalignment in the foreign and domestic sectors, which led to persistent balance of payment deficit and to channel a path of economic recovery and growth. The main policy thrust involves removal of non-tariffs obstacles, introduction of markets forces as a medium of foreign exchange rate determination and fiscal disincentives and regulatory measures that deter exports [3].

The exchange rate policy was established from the aggregate aims of achieving macroeconomic management to ensure internal and external balance in the medium and long term. Internal balance refers to the level of economic activities that is in line with checking the side effects of inflation [4], while external balance refers to balance of payment equilibrium or sustainable current account deficit financed on a lasting basis by expected capital inflow [5]. In view of revisiting the over-valuation of exchange rate policy regime i.e fixed exchange rate, the second-tier foreign exchange market (SFEM) was introduced in September, 1986. The SFEM was centred on finding more realistic exchange rate for the domestic currency through market forces, leading to the depreciation of the currency in the exchange market. It becomes imperative that much expected realistic exchange rate would brings down excessive demand for foreign exchange and more importantly, for importation of finished goods and services.

But at the theoretical level, it was believed that a rise in exchange rate, will lead to the fall in the value of the domestic currency vis-à-vis the rest of the world, leading to a situation where exports becomes less expensive for the rest of world because foreign currency automatically gains value and hence, exports are expected to rise. In the same vein, imports are expected to reduce as the rest of the world's commodities become more costly for domestic residents. To this end, favourable balance of trade should be expected. However, Alfred Marshall and Abba Lerner further submitted that a rise in exchange rate can bring about favourable balance of trade only if elasticity of demand for exports by the rest of the world and at the same time, demand for imports by domestic residents is strong enough. The rest of the paper will be divided as follows; section two, present the review of related Literature and theoretical framework, section three, the methodology and model specification, section four, empirical result and discussion, section five, Conclusion.

\section{Review Of Related Literature And Theoretical Framework}

[6], in her book titled Exchange rate determination, she tried to justified the J-curve hypothesis by arguing that by the time exchange rate is be determined, goods already in transit and under contract have been purchased, creating a situation leading to time lag in the impact of exchange rate determination changes. With the transactions already in progress prior to the exchange rate adjustments are decided subsequently by commercial activity, reflecting a new competitive environment and with new exchange regime, giving room for the improvement in the balance of trade.

[7], identified the existence of J-curve hypothesis in Croatia economy, the study employed ARDL Cointegration approach for quarterly data. He identified long-run relationship, showing that at one percent depreciation, an improvement of $0.9 \%$ to $1.3 \%$ in balance of trade was recorded. More so, the estimated impulse further shows that it takes two and half years to achieve the above improvement. But the negative impact of depreciation only occurred in the short-run. His study employed a reduced form model to estimate the impact of a permanent shock on the merchandise trade balance.

[8], they opined that real devaluation has significant impact on national incomes. They further argue that developed countries are likely to gain more from devaluation than it would benefit small economies. A small economy tends to experience a fall in national income as a result of devaluation.

[9] analyze the reactions of real exchange rates and trade balance to monetary policy shocks by using a structural VAR model. Their submission confirmed that trade balance and which is correlated with the appreciation of the exchange rates, subsequently deteriorates the balance of trade, thus confirming the J-curve hypothesis. 
[10] employed the use of non-parametric methods that give room for non-linearity to examine the statistical relationship between current-account, exchange rate and GDP. Their findings confirmed the present of J-curve hypothesis in the data but not its standard explanation. They discovered that a rise in the current account is associated with decline in GDP, but this is a clear contradiction that at long-run that at long-run balance of trade will improve after initial depreciation through the increase in foreign demand, improving the domestic GDP.

[2], in their theoretical reviewed, they opined that trade balance following currency devaluation may be generated by five lags; they includes recognition of the new value of the currency by both producers and consumers, a lag in decision by both producer and consumer to change, a lag in delivery time, lag in the replacement of inventory and material on the part of producers and lag in production caused by the production cycle.

[11] employing the quarterly data for 1960-1985, at bilateral level between U.S and its six largest trading partners. Their finding did not confirm the existence of J-curve pattern or long-run relationship between bilateral exchange rate and trade flows. [12] investigated the dynamics between the U.S dollar and components of U.S trade. Using time series-specification test and Granger causality test to investigate the J-curve hypothesis, two of the four components show a dynamic correlation that are weaker and more delayed than J-curve. J-curve confirmed a strong and rapid dependency of import prices on the currency.

[13] examines the macroeconomic determinants of Korea continued bilateral trade deficit with Japan and its favourable term of trade with the U.S. He employs Johansen Cointegration and error correction model on variables such as the trade balance, real exchange rate, domestic and foreign incomes and relative money supply. The study established that all variables exact influence on bilateral trade balances and discovered that long-run equilibrium exist among the variables. The J-curve effect was established between Korea and Japan.

[14] believed that after currency devaluation, the contracts that have been concluded at the old exchange rate dominate the short-run response of trade balance. But with time the emergence of new trade contract at relatively competitive prices begin to affect their favourable effect on trade volumes and exact positive influence on elasticities and thus improving the trade leading to J-curve hypothesis.

[15] conducted a test of the J-curve effect in Turkey, looking at bilateral trade effect between Turkey and thirteen biggest trading partners between 1985-2005. The study employed Cointegration statistical model, using six different lags to account for the pass-through period, the study tested whether currency fluctuations was statistically relevant causation for trade balance. The study discovered that in all thirteen cases, exchange rate have no effect on bilateral trade in the short-run and only limited effect in the long-run with the two of the countries i.e. U.S and U.K.

[16] analyze the effect of term of trade on the U.S trade balance following a declining term of trade for the period 1947-1974. But [17] found that devaluation do not exact positive influence on trade balance but do improve the balance of payments. He further advised that depreciation of currency in readjustment in investment portfolio leading to an excess in capital account.

\section{2:1 Theoretical Framework}

According to [18], the trade balance consist of both merchandise components of exports and imports, domestic income and prices of imports are main factors of demand for imported goods. This can be shown thus;

$$
D_{d}=D_{d}\left(Y, P_{d}, P_{c}\right)
$$

Where $D_{d}=$ domestic demand for imports, $P_{d}=$ domestic currency price and $P_{c}$ is the general price level in the domestic country. In the same vein, domestic produced goods (equivalent to export demanded by foreigners) to the rest of the world is shown thus;

$$
\mathbf{F}_{\mathrm{d}}=\mathbf{F}_{\mathrm{d}}\left(\mathbf{Y}^{*}, \mathbf{P}_{\mathrm{g}}, \mathbf{E}, \mathbf{P}_{\mathrm{h}}\right)
$$

Where $F_{d}$ is the quantity of export goods to the rest of the world, $\mathrm{Y}^{*}$ is the foreign income, $\mathrm{P}_{\mathrm{g}}$ is the foreign currency price paid by domestic importers, $\mathrm{Ph}$ is the general price level in the foreign country and $\mathrm{E}$ is the nominal exchange rate defined as the number of units of domestic currency per one unit of foreign currency. The vital assumption underlying the equations (1) \& (2) are that both domestic and foreign income elasticities are positive, so is the cross price elasticity, while the own price elasticity is negative.

In the above model, demand variables are current income but permanent or transitory income, this brings about homogeneity assumption be made by the Economists. In order to impact the homogeneity assumption, the right hand sides of both equations (1) \& (2) are divided by their respective prices and the equations can be shown thus;

$$
\begin{aligned}
& \mathbf{D}_{\mathbf{d}}=\mathbf{D}_{\mathbf{d}}\left(\mathbf{Y}_{\mathrm{r}}, \mathbf{R T P}_{\mathrm{m}}\right) \\
& \text { Where } \mathrm{Y} \curlyvee \text { represent real domestic income and } \mathrm{RTP}_{\mathrm{m}} \text { represent relative price of imports and } \\
& \mathbf{F}_{\mathrm{d}}=\mathbf{F}_{\mathrm{d}}\left(\mathbf{Y}^{*}, \mathbf{R T P}_{\mathrm{x}}\right)
\end{aligned}
$$

Where $\mathrm{Y}^{*}$, represent the real domestic income and $\mathrm{RTP}_{\mathrm{x}}$ represent relative price of exports. In a situation where foreign currency price of foreign exports, $\mathrm{Pg}$ is adjusted for exchange rate, it is equal to the relative price of imports, thus we arrive at following equation; 
$\mathbf{R T P m}=\underline{\mathbf{P}}_{\mathrm{d} /} \mathbf{P}_{\mathrm{c}}=\mathbf{E} \underline{\mathbf{P}}_{\mathrm{g} /} \mathbf{P}_{\mathrm{c}}=\mathbf{E} \underline{p}_{\mathrm{g} /} \mathbf{P}_{\mathrm{c}}=\mathbf{E} \underline{P}_{\mathrm{h} /} \mathbf{P}_{\mathrm{c}} \quad \underline{\mathbf{P}}_{\mathrm{g} /} \mathbf{P}_{\mathrm{c}}=\mathbf{Q P} \mathbf{P}_{\mathrm{g}}$

$\mathrm{P} * \mathrm{~g}$ represent the real foreign currency price of exports, $\mathrm{Q}$ stands for real exchange rate in the above equation, a rise in $\mathrm{Q}$ represent devaluation of domestic currency. Since domestic exports are foreign imports and the collolary is true, domestic import demand equal foreign export supply and domestic export supply is equal to foreign import demand and hence, we derive equation 6 ,

$$
D_{d}=X_{s}^{*}, \quad F_{d}=M^{*}{ }_{s}
$$

Where $\mathrm{X} * \mathrm{~s}$ and $\mathrm{M} * \mathrm{~s}$ represent foreign export supply and foreign import supply respectively and hence, we derive long-run equation for the trade balance thus;

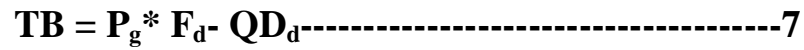

The above equation (7) shows that Trade balance represents the difference between the value of exports and imports. A situation where TB is negative, it stands for trade deficit and represent a rise in the value of imports relative to exports. The interaction of the variables in above equation (7) leading to the following reduced form equation in real values and this is derived in equation (8)

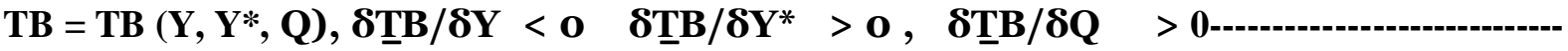 $---8$}

The above equation is the traditional Keynesian function for the trade balance where real exchange rates are the main determinants of net exports.

\section{Model Specifications}

Based on the equation (7) under theoretical framework, trade balance is expected to be influenced by the real exchange rate and a measure of both domestic and foreign income respectively. Upon preliminary testing, it was discovered that foreign income is not statistically significant and hence, the following model to be estimated;

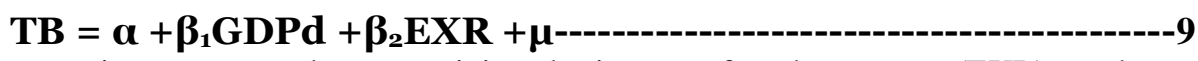

From the above, our interest centred on examining the impact of exchange rate (EXR) on the trade balance (TB) i.e whether in the long-run real depreciation of currency will improve trade balance and other way round in the case of appreciation. The a priori expectation for the assumption to hold, the coefficient on real exchange rate should be positive: $\beta 2>0$. In order to estimate the impact of exchange rate on trade balance, we need to control for the impact of domestic income, and this necessitate the need to include GDP in equation (9).

\section{3:1 Sources Of Data}

Time series data generated from central bank of Nigeria (statistical bulletin), national bureau statistics and UN Conference on Trade and Development (Unctdstat 2011) and from 1980-2010. An econometrics model will be developed to examine the relationship between trade balance and real exchange rate in Nigeria in order to test for existence J-curve hypothesis.

\section{Result And Analysis Of The Estimates}

Table 1a: ADF Unit Test (Trend and Intercept)

\begin{tabular}{|l|c|c|c|l|}
\hline Variables & ADF Test Statistics & Critical Values & \multicolumn{1}{|l|}{$\begin{array}{l}\text { Level of } \\
\text { Sig }\end{array}$} & $\begin{array}{l}\text { Order of } \\
\text { Integration }\end{array}$ \\
\hline TB & -3.9972 & -3.5742 & $5 \%$ & $1(1)$ \\
\hline GDP & -8.3266 & -4.3098 & $1 \%$ & $1(1)$ \\
\hline Nomexch & -5.0637 & -4.3240 & $1 \%$ & $1(1)$ \\
\hline
\end{tabular}

Table 1b: PP Unit Test (Trend and Intercept)

\begin{tabular}{|l|c|c|c|c|}
\hline Variables & PP Test Statistics & Critical Values & Level of Sig & Order of Integration \\
\hline TB & -3.9421 & -3.5742 & $1 \%$ & $1(1)$ \\
\hline GDP & -10.5365 & -4.3098 & $1 \%$ & $1(1)$ \\
\hline Nomexch & -5.0618 & -4.3240 & $1 \%$ & $1(1)$ \\
\hline
\end{tabular}

The tables 1 and 2 above indicates that variables are non-stationary using both Augmented Dickey Fuller and Phillips Peron test for stationary. In ADF test, all the variables with exception TB were to be stationary at first difference with $1 \%$ level of significant, while TB is found at $5 \%$ level of significant. While under Phillips Peron, all the variables were stationary at first difference and $1 \%$ level of significant. Then, we go further to examine the long-run relationship using Johasen cointegration test for the variables using both the trace and max-eigen value tests. 
Table 2: Johasen Cointegration Test

Date: $12 / 30 / 12$ Time: 08:41

Sample (adjusted): 19822009

Included observations: 28 after adjustments

Trend assumption: Linear deterministic trend

Series: TB NOMEXCH GDP

Lags interval (in first differences): 1 to 1

Unrestricted Cointegration Rank Test (Trace)

\begin{tabular}{|l|l|l|l|l|}
\hline \hline $\begin{array}{l}\text { Hypothesized } \\
\text { No. of CE(s) }\end{array}$ & Eigenvalue & $\begin{array}{l}\text { Trace } \\
\text { Statistic }\end{array}$ & $\begin{array}{l}0.05 \\
\text { Critical Value }\end{array}$ & Prob.** \\
\hline \hline None & 0.396740 & 25.95858 & 29.79707 & 0.1299 \\
At most 1 & 0.297825 & 11.80717 & 15.49471 & 0.1664 \\
At most 2 & 0.065844 & 1.907133 & 3.841466 & 0.1673 \\
\hline \hline
\end{tabular}

Trace test indicates no cointegration at the 0.05 level

* denotes rejection of the hypothesis at the 0.05 level

**MacKinnon-Haug-Michelis (1999) p-values

Unrestricted Cointegration Rank Test (Maximum Eigen value)

\begin{tabular}{|l|l|l|l|l|}
\hline \hline $\begin{array}{l}\text { Hypothesized } \\
\text { No. of CE(s) }\end{array}$ & Eigen value & $\begin{array}{l}\text { Max-Eigen } \\
\text { Statistic }\end{array}$ & $\begin{array}{l}0.05 \\
\text { Critical Value }\end{array}$ & Prob.** \\
\hline \hline None & 0.396740 & 14.15141 & 21.13162 & 0.3527 \\
At most 1 & 0.297825 & 9.900037 & 14.26460 & 0.2186 \\
At most 2 & 0.065844 & 1.907133 & 3.841466 & 0.1673 \\
\hline \hline
\end{tabular}

Max-eigenvalue test indicates no cointegration at the 0.05 level

* denotes rejection of the hypothesis at the 0.05 level

**MacKinnon-Haug-Michelis (1999) p-values

The above clearly shows from both the trace and max-eigen value that no cointegration exist among the variables under consideration and this implies that there is instability in the relationships among the three variables under consideration and it becomes imperative to estimate vector autogression of the variables and this can be shown thus;

Table 3: Vector Auto-regression Estimates of TB, NOMEXCH and GDP

Vector Autoregression Estimates

Date: 12/30/12 Time: 08:48

Sample (adjusted): 19822009

Included observations: 28 after adjustments

Standard errors in ( ) \& t-statistics in [ ] 


\begin{tabular}{|c|c|c|c|}
\hline & $\mathrm{TB}$ & NOMEXCH & GDP \\
\hline $\mathrm{TB}(-1)$ & $\begin{array}{l}1.029784 \\
(0.26353) \\
{[3.90764]}\end{array}$ & $\begin{array}{l}-1.19 \mathrm{E}-05 \\
(6.8 \mathrm{E}-06) \\
{[-1.75068]}\end{array}$ & $\begin{array}{l}1.364953 \\
(1.82901) \\
{[0.74628]}\end{array}$ \\
\hline $\mathrm{TB}(-2)$ & $\begin{array}{c}-0.443116 \\
(0.25709) \\
{[-1.72357]}\end{array}$ & $\begin{array}{l}9.77 E-06 \\
(6.6 E-06) \\
{[1.47200]}\end{array}$ & $\begin{array}{l}1.578835 \\
(1.78432) \\
{[0.88484]}\end{array}$ \\
\hline $\operatorname{NOMEXCH}(-1)$ & $\begin{array}{r}-2767.407 \\
(7996.60) \\
{[-0.34607]}\end{array}$ & $\begin{array}{l}1.067124 \\
(0.20634) \\
{[5.17168]}\end{array}$ & $\begin{array}{l}19348.05 \\
(55499.5) \\
{[0.34862]}\end{array}$ \\
\hline NOMEXCH(-2) & $\begin{array}{c}11414.11 \\
(8991.52) \\
{[1.26943]}\end{array}$ & $\begin{array}{c}-0.007250 \\
(0.23201) \\
{[-0.03125]}\end{array}$ & $\begin{array}{l}33852.70 \\
(62404.6) \\
{[0.542471}\end{array}$ \\
\hline $\operatorname{GDP}(-1)$ & $\begin{array}{l}0.030052 \\
(0.03119) \\
{[0.96347]}\end{array}$ & $\begin{array}{l}9.99 \mathrm{E}-08 \\
(8.0 \mathrm{E}-07) \\
{[0.12409]}\end{array}$ & $\begin{array}{l}0.072899 \\
(0.21648) \\
{[0.33675]}\end{array}$ \\
\hline $\operatorname{GDP}(-2)$ & $\begin{array}{r}-0.020096 \\
(0.03259) \\
{[-0.61663]}\end{array}$ & $\begin{array}{l}4.98 \mathrm{E}-07 \\
(8.4 \mathrm{E}-07) \\
{[0.59265]}\end{array}$ & $\begin{array}{l}0.024259 \\
(0.22618) \\
{[0.10725]}\end{array}$ \\
\hline $\mathrm{f}$ & $\begin{array}{l}-33283.82 \\
(154836) \\
{[-0.21496]}\end{array}$ & $\begin{array}{l}3.502959 \\
(3.99529) \\
{[0.87677]}\end{array}$ & $\begin{array}{l}829699.4 \\
(1074619) \\
{[0.77209]}\end{array}$ \\
\hline $\begin{array}{l}R \text {-squared } \\
\text { Adj. } R \text {-squared }\end{array}$ & $\begin{array}{l}0.905054 \\
0.877926\end{array}$ & $\begin{array}{l}0.950690 \\
0.936601\end{array}$ & $\begin{array}{l}0.816013 \\
0.763445\end{array}$ \\
\hline $\begin{array}{l}\text { Akaike } \\
\text { criterion }\end{array}$ & 71.41308 & & \\
\hline
\end{tabular}

The Estimation of VAR in levels shows that Nomexch has the highest R-square of $95 \%$ but at not statistically significant at $5 \%$ level of in both lags in respect of trade balance. This implies that exchange rate provides no information as its impact on trade balance. The relationship can further be examining using Variance decomposition. The dynamic relationship of the trade balance with respect of real exchange and GDP can be examined in term of variance decomposition. The importance attributes of variance decomposition analysis is to make available vital information in respect of relative importance of random innovations , [19] using variance decomposition, we arrived at some information on various percentages of variation in the forecast error of a variable as explained by its own innovation and proportion explained by innovations in other variables in the systems. The table 4 below provides information on variance decomposition of trade balance as attributable to its own innovations and shocks in other variables for a forecast.

\section{Table 4: Variance Decomposition of TB}

Period
\begin{tabular}{|l|l|l|ll|l}
\hline & S.E. & TB & NOMEXCH & GDP GDP \\
\hline \hline 1 & 575204.0 & 100.0000 & 0.000000 & 0.000000 & \\
2 & 845923.0 & 97.81904 & 0.234671 & 1.946288 & \\
3 & 950564.5 & 97.08553 & 1.094992 & 1.819482 & \\
4 & 999677.8 & 90.59778 & 7.755644 & 1.646575 & \\
5 & 1074901. & 78.68015 & 19.89006 & 1.429795 & \\
6 & 1184550. & 67.38310 & 31.43906 & 1.177836 & \\
7 & 1291304. & 59.24101 & 39.72455 & 1.034439 & \\
8 & 1373232. & 53.34024 & 45.59187 & 1.067889 & \\
9 & 1435376. & 48.85599 & 49.89790 & 1.246106 & \\
10 & 1491966. & 45.43950 & 53.08323 & 1.477271 & \\
& & & & \multicolumn{2}{|l|}{}
\end{tabular}

The outcome of the variance decomposition suggest that for Nigeria in Table 4 above shows the important source of variation in the trade balance forecast error is its own innovations and reduces overtime with average of $24.7 \%$ for the forecast horizon. The real effective exchange accounts for about an average of $24.7 \%$ of the variation in the trade balance, while GDP accounts for about an average of $1.29 \%$ respectively. This result suggest that real exchange rate has little influence on the variations in trade balance in the long-run and but the short-run dynamic can be examine through the Granger causality test. 
Null Hypothesis

Table 5: GRANGER CAUSALITY TEST F- Value

\begin{tabular}{|l|c|c|c|c|}
\hline & 1 & 2 & 3 & 4 \\
\hline$\Delta$ NOMEXCH does not granger causes $\Delta$ TB & 6.56 & 3.59 & 5.03 & 4.21 \\
\hline$\Delta$ TB does not granger causes $\triangle$ NOMEXCH & 0.30 & 1.53 & 2.37 & 1.90 \\
\hline
\end{tabular}

The above standard granger causality result shows bidirectional causality between real exchange rate trade balance but associated level of significant shows that the relationship runs from real exchange rate to trade balance is stronger and this confirm the presence of J-curve hypothesis in Nigerian economy in the short-run.

\section{Conclusions}

The study analyze the impact depreciation of naira for the period of 1980-2010, on the trade balance in the Nigeria economy, the study shows that J-curve hypothesis do apply to Nigeria economy under consideration with the bidirectional causality between real exchange rate and trade balance but with associated level of significant shows that the relationship runs from exchange rate to trade balance is stronger. For the economy to benefit from the initial devaluation of the domestic currency in the long-run, efforts should made to diversified the economy from be mere monoculture economy and develop other sectors of the economy that can contribute to the national economy. The issue of instability in world oil market couple with the crisis in the oil producing area in the country seriously affects the volume of revenue accrued to the country. More so, the devaluation of currency ordinarily would increase the volume of exports but quite unfortunately, the country only relied on oil sector but the price of the product and the quantity to be produced were determined by Organization of petroleum exporting countries (OPEC). This necessitates the need for to open-up other sectors of the economy and improve the export bases of the country, so as to benefit from the initial devaluation of the domestic currency.

\section{References}

[1] Kulkarni, K. Readings in International Economics. New Delhi: Serial Publication 2007.

[2] Junz, H.B., and R. R. Rhomberg, "Price Competitiveness in Export Trade among Industrial Countries", American Economic Review $63,412-418,1973$

[3] Agbeyegbe, T., Stotsky, J. and A. WoldeMariam. "Trade Liberalization, Exchange Rate Change and Tax Revenue in Sub-Sahara Africa, Hunter College Department of Economics Working Papers No403, 2004.

[4] Williamson, J. The Exchange Rate System: Washington D.C, Institute for International Economics, 1982.

[5] Komolafe, O.R, "Exchange Rate Policy and Nigeria's External Sector Performance", Nigeria's Journal of Economics and Social Studies, Vol. 38, 1996.

[6] Krueger, A.,'Exchange Rate Determination". Cambridge University Press, 1983.

[7] Stucka, T, "The Impact of Exchange Rate Changes on the Trade Balance in Croatian National Bank Working Paper Series, No W11 , October 2003

[8] Gylfason, T. and Risager, O. Does Devaluation Improve the Current Account? European Economic Review, $25,1984$.

[9] Koray, F. and McMillan, W.D, Monetary Shocks, the Exchange Rate and the Trade Balance, Journal of International Money and Finance, 18, 925-940, 1999

[10] Leonard, G. and Stockman, A.C., Current Account and Exchange Rates: A New looks at the Evidence, NBER Working Paper No: $8361,2001$.

[11] Rose, A.K and Yellen, J. L, "Is there a J-Curve?" Journal of Monetary Economics 24: 53-64, 1989.

[12] Koch, P. and Rosensweig, J., The Dynamic Relationship Between the Dollar and the Components of U.S Trade, Journal of Business and Economic Statistics, 8(3),355-364,1990.

[13] Kim, A. An empirical analysis of Korea's trade imbalance with the U.S.A and Japan. Journal of the Asia Pacific Economy, Vol.114, No.3, 211-226, 2009.

[14] Magee, S.P, “currency Contracts, pass through, and Devaluation”. Brookings Papers of Economic Activity, 1: 303 -325, 1973.

[15] Halicioglu, S. and Stone, J.,"The J-curve Dynamic of Turkey: An application of ARDL Model”, Applied Economics, Vol.40, No18, PP. 2423-2429, 2008.

[16] Haynes, S. and Stone, J. Impact of the terms of trade on the U.S trade Balance: a reexamination of Miles's (New Results). Journal of International Money and Finance, 4, 553-563, 1982.

[17] Miles, M.A, The Effects of Devaluation on the Trade Balance and the Balance of Payments: Some new result. Journal of Political Economy 87(3), 600-620, 1979.

[18] Goldstein, M and Khan, M.S. Income and Price Effects of in Foreign Trade, Handbook of International Economics, 2, 1041-1105, 1985.

[19] Narayan, P.K and Narayan, S. The J-curve: Evidence from Fiji: International Review of Applied Economics, 18(3), 369-380, 2004. 